\title{
Peningkatan Kemampuan Berbicara Mahasiswa Menggunakan Teknik Voice Over
}

\author{
Voice Over Technique to Improve the Students' Speaking Skill
}

\author{
Arief Zul Fauzi*1, Dani Fitria Brilianti ${ }^{2}$, Bahri Kamal ${ }^{3}$ \\ 1,3 Program Studi DIII Akuntansi, Politeknik Harapan Bersama, Indonesia \\ ${ }^{2}$ Program Studi DIII Teknik Komputer, Politeknik Harapan Bersama, Indonesia \\ e-mail: arief.zulfauzi@poltektegal.ac.id
}

\begin{abstract}
Abstrak
Pembelajaran daring semasa pendemi cenderung menjadikan pelajar, khususnya mahasiswa menjadi pasif dalam berbicara. Banyak dari mereka mengaku takut untuk berbicara karena beberapa hal, seperti ketidaktahuan cara membaca dan merasa tidak percaya diri akan suara yang dimiliki. Kegiatan ini bertujuan untuk meningkatkan kemampuan berbicara mahasiswa serta memberikan pengetahuan tentang teknik berbicara voice over (VO) yang termasuk baru bagi mahasiswa. Metode yang digunakan adalah pelatihan dan pendampingan praktik secara daring melalui aplikasi Zoom Meeting. Di akhir pelatihan, peserta pelatihan memberikan produk berupa perangkat audio-visual sebagai hasil pengaplikasian materi yang diberikan selama pelatihan.
\end{abstract}

Kata kunci - kemampuan berbicara, mahasiswa, voice over, daring.

\begin{abstract}
Online learning during a pandemic tends to make students, especially students, become passive in speaking. Many of them admitted that they were afraid to speak for several reasons, such as not knowing how to read and feeling insecure about their voice. This activity was aimed to improve students' speaking skills and provide knowledge about voice over (VO) speaking techniques which are new for students. The method used was online training and practical assistance through the Zoom Meeting application. At the end of the training, the training participants provided products in the form of audio-visual devices as a result of applying the material provided during the training.
\end{abstract}

Keyword-speaking skill, students, voice over, online.

\section{PENDAHULUAN}

Penyesuaian dalam sektor Pendidikan di saat pandemi Covid-19 meliputi proses pembelajaran yang disesuaikan dari jenjang dasar hingga jenjang tinggi. Pembelajaran yang awalnya dengan tatap muka, aktivitas kelas, maupun aktivitas eksplorasi seperti penggunaan fasilitas laboratorium dan kerja praktek ditiadakan dan diganti dengan kegiatan yang dianggap setara dalam pelaksanaan pembelajaran di lingkungan akademik baik itu di lingkungan pendidikan formal maupun informal. Konsekuensinya, kemandirian belajar dituntut menjadi lebih tinggi kepada peserta didik sehingga tidak hanya pengajar sebagai sumber pengetahuan yang melakukan tugas pendidikan namun juga peserta didik tersebut dan juga terkadang dengan pendampingan orang tua sebagai faktor afeksi pada saat proses pembelajaran jarak jauh yang dilaksanakan pada tiap satuan pendidikan. Kebijakan pembelajaran online di masa pandemi COVID19 menjadi solusi utama agar proses pembelajaran dapat terus berjalan. Namun ada kendala dan kekurangan dalam proses pelaksanaannya (Pawicara \& Conilie, 2020). Fenomena pembelajaran jarak jauh / dalam jejaring (daring) ini ada kalanya menjadi beban pada aspek pendukung pendidikan, baik dari sisi pengajar maupun sisi peserta didik. Kurangnya motivasi dan "tekanan" dalam belajar sering terjadi pada proses pembelajaran jarak jauh dan dianggap kurang dapat mengoptimalkan kemampuan diri pengajar maupun peserta didik. Sistem

Submitted: Juli 2021, Accepted: Agustus 2021, Published: Agustus 2021

ISSN 2746-6345 (media online) 
pembelajaran yang tidak efisien dapat membuat penyampaian materi sulit dipahami (Vitasari, 2016). Proses pembelajaran dikesankan hanya bergantung dari pengajar yang memberikan pengetahuan pada tiap proses pembelajaran jarak jauh yang dilaksanakan menggunakan mediamedia daring tersebut. Bersumber pada bermacam kasus yang dialami oleh peserta didik di lingkungan akademik, terpaut momok serta beratnya proses pendidikan daring. Oleh karena itu, kebutuhan suatu media ataupun tata cara yang bisa dengan mudah diterima mahasiswa di luar kelas merupakan sebuah hal yang tidak dapat ditawar. Media ataupun Teknik tersebut selayaknya diintegrasikan kepada banyak aspek, tidak hanya terbatas pada perkuliahan dalam lingkup akademik tetapi juga dapat diaplikasikan sebagai kemampuan tambahan bagi mahasiswa. Salahsatu kemampuan yang dapat diasah dalam lingkup akademik dan dapat pula menjadikan manfaat di luar adalah kemampuan berbicara. Berbicara dipercaya sebagai kemampuan berbahasa yang paling penting (Ur, 2012). Hal tersebut dapat kita ketahui juga bersama dari penilaian berbicara dalam berkomunikasi baik dalam penilaian akademik ataupun pada perlombaan, kemampuan berbicara menjadi tolak ukur seseorang dapat berkomunikasi dengan baik. Keberhasilan seorang dikala berhubungan dalam meresap bermacam pesan serta data yang di informasikan oleh lawan bicara, sehingga lewat keahlian ini lawan bicara bisa memperhitungkan sepanjang mana keahlian berbicara seorang bisa disimpulkan (Hsu et al., 2013).

Salah satu teknik dalam kemampuan berbicara yang dapat dilakukan oleh setiap orang adalah teknik Voice Over (VO). Voice over termasuk teknik naratif, di mana suara narator tanpa wajah terdengar melalui gambar yang berbeda dan ini untuk tujuan yang berbeda (Franco et al., 2010). Teknik ini menyatukan antara kemampuan berbicara dan pemasaran. Biasanya penggunaan VO dilakukan pada proses pembuatan iklan produk ataupun pembacaan naskah resmi dalam berbagai kesempatan. Dalam info komersial, iklan, dan video promosi, kegunaan voice over adalah untuk memberikan informasi tambahan tentang suatu produk atau layanan. Acara-acara televisi dan film-film sering mempekerjakan pekerja di bidang itu untuk menceritakan elemen-elemen plot penting. Selain itu, voice over juga sering digunakan untuk mengisi suara dialog pada film atau serial animasi. Pengisian suara ini digunakan untuk memperkuat karakter tokoh di dalam animasi. Selain digunakan di dunia hiburan, voice over juga digunakan untuk jurnalistik. Biasanya, pengisian suara ini digunakan untuk memberi penjelasan dari berita yang ditayangkan. Teknik ini diharapkan juga akan menjadi salah satu kemampuan tambahan bagi mahasiswa dalam melatih kemampuan berbicara. Kemampuan bicara juga dapat dilaksanakan pada saat pelatihan wawancara kerja dalam Bahasa Inggris (Ubaedillah, 2020).

Tujuan program pengabdian masyarakat ini adalah untuk tercapainya beberapa hasil manfaat yang dapat diraih berupa ketertarikan mahasiswa untuk berbicara secara langsung maupun tidak langsung untuk umum, adanya kenaikan kepercayaandiri mahasiswa untuk berbicara secara langsung maupun tidak langsung, dan kenaikan kemampuan berbicara dalam membawakan penampilan / pemaparan secara audio-visual.

Dari pandangan dan realita yang terjadi di lapangan, dapat ditemuka sebuah permasalahan yang mendorong untuk diadakannya Pengabdian Kepada Masyarakat ini. Permasalahan yang terjadi pada subyek pengabdian masyarakat ini-mahasiswa di Program Studi D-III Akuntansi Politeknik Harapan Bersama-yaitu ketakutan dan ketidakpercayadirian ketika berbicara baik secara langsung depan umum maupun tidak langsung. Secara langsung, dapat berpengaruh terhadap kemampuan berbicara mahasiswa selama ini.

Beberapa pelaksanaan kegiatan sekaligus penelitian telah diselidiki oleh beberapa peneliti yang berfokus pada kecemasan keterampilan berbicara siswa. Safitri \& Khoiriyah (2017) membahas tentang persepsi siswa tentang penggunaan vlog bahasa Inggris untuk meningkatkan keterampilan berbicara mereka dan untuk mengetahui strategi siswa untuk meningkatkan keterampilan berbicara siswa dengan menggunakan video blog bahasa Inggris (vlog).. Data dikumpulkan dari wawancara siswa, observasi, dan dokumen. Hasil penelitian menunjukkan bahwa proses belajar mengajar yang menggunakan media vlog bahasa Inggris secara signifikan meningkatkan keterampilan berbicara siswa. 
Indrianty (2016) meneliti kecemasan siswa dalam berbicara bahasa Inggris yang dinilai di Kolase Hotel dan Pariwisata Bandung. Penelitian ini mengidentifikasi jenis kecemasan dan sumber kecemasan siswa dalam berbicara. Studi ini mengungkapkan dua temuan terkait dengan pertanyaan penelitian. Pertama, ada dua jenis kecemasan yang dibuktikan yaitu kecemasan sifat dan kecemasan situasional. Kedua, kecemasan siswa dalam berbahasa Inggris disebabkan oleh tiga faktor yaitu ketakutan komunikasi, ujian, dan ketakutan. Selain itu, data wawancara mengungkapkan, kurangnya kosakata dan persiapan siswa juga berkontribusi pada kecemasan siswa dalam berbicara. Sebuah temuan menyarankan bahwa sebagai guru harus memberikan motivasi yang tinggi kepada siswa dan memikirkan media yang efektif untuk memecahkan masalah. Penggunaan metode pelatihan dan pembelajaran secara online juga memiliki dampak meningkatnya kemampuan belajar mahasiswa (Fauzi \& Brilianti, 2021). Secara umum, mahasiswa tertarik dengan penggunaan metode-metode maupun media yang selama ini belum pernah diaplikasikan selama perkuliahan oleh pengajar di perkuliahan sebelumnya.

Peningkatan sumber daya manusia dapat dilakukan ditingkatkan melalui pelatihan (Rijanto \& Rahayuningsih, 2021). Dengan dilaksanakannya kegiatan pengabdian berupa pelatihan berbicara menggunakan Teknik voice over ini, diharapkan para mahasiswa dapat mengetahui dan meningkatkan kemampuan berbicaranya. Keahlian dalam berbicara tidak lepas dari kecermatan dalam kemampuan berbahasa. Keahlian mencermati ialah salah satu keahlian yang sangat kerap digunakan, tidak hanya keahlian berdialog ataupun speaking skill, oleh pembelajar dalam berbicara serta berhubungan satu sama lain, baik sesama pembelajar ataupun dengan pengajar (Brilianti \& Fithriyani, 2020). Tidak hanya sekedar mengetahui teknik membaca dari apa yang selama ini dipelajari dalam perkuliahan secara umum. Kedepannya, juga dapat dimanfaatkan sebagai salah satu soft skill yang dapat menghasilkan pendapatan sebagai voice over talent atau dubber jika ada kesempatan yang dapat dimanfaatkan oleh mahasiswa.

\section{METODE PELAKSANAAN}

Sasaran kegiatan pengabdian kepada masyarakat ini adalah mahasiswa Program Studi DIII Akuntansi Politeknik Harapan Bersama. Metode pelaksanaan kegiatan dalam program pengabdian masyarakat yang dilakukan adalah terkait dengan perumusan masalah yang telah diungkapkan. Adapun langkah-langkah atau metode pelaksanaan diawali dengan pemetaan (mapping). Pemetaan dilakukan pada saat menganalisis situasi denga memetakan permasalahan apa yang dihadapi dan solusi apa yang dibutuhkan. Dari hasil pemetaan yang dibutuhkan mahasiswa adalah kegiatan positif untuk meminimalisir ketakutan berbicara di depan umum. Seletah dilaksanakan mapping, dilaksanakan langkah selanjutnya yaitu wawancara. Wawancara juga dilakukan kepada mahasiswa dan pengajar program studi DIII Akuntansi Politeknik Harapan Bersama terkait dengan permasalah yang dihadapi oleh siswa terutama yang berkaitan dengan penampilan berbicara di depan umum. Thornbury (2006) menyatakan bahwa esensi berbicara adalah suatu proses struktur struktur bahasa yang berubah dari tertulis menjadi lisan. Dalam proses belajar mengajar bahasa, pengertian keterampilan berbicara adalah kemampuan berlatih atau mengembangkan bahasa secara terus menerus dan mandiri untuk mengungkapkan ide, pendapat, perasaan, keyakinan, dan pemikiran orang dalam bahasa tertentu. Pada akhirnya, dari perumusan masalah dilakukan dengan tujuan mencari solusi yang dapat dilakukan. Solusi yang dihasilkan adalah pelaksanaan pelatihan guna meningkatkan kemampuan berbiacara mahasiswa dengan mengenalkan dan mempraktikkan teknik voice over.

Pelaksanaan Pengabdian Kepada Masyarakat ini dilakukan secara daring menggunakan Zoom Meeting dengan menggunakan metode ceramah, tutorial dan diskusi. Tim pengabdi sebagai pemateri memberikan bekal berupa pemahaman dan tutorial seputar teknik voice over. Pemilihan Zoom Meeting sebagai media pelatihan tidak terlepas dari segala bentuk dan fitur kemudahan yang ditawarkan. Zoom Meeting ini dinilai praktis dan efisien bagi siswa, karena dengan menggunakan Zoom Meeting ini, komunikasi antara siswa dan guru lebih mudah daripada menulis atau sekedar mengirimkan pesan (Haqien \& Rahman, 2020). 
Diawali dengan metode ceramah, peserta diberikan motivasi tentang pentingnya memiliki keahlian berbicara di depan umum. Peserta juga diberikan gambaran tentang keuntungan yang dapat dimiliki jika mampu mengembangkan kemampuan berbicara di depan umum. Kemudian dilaksanakan tutorial, peserta diberikan materi dan praktek berbicara dengan teknik voice over oleh pemateri secara daring. Setelahnya, peserta pelatihan diberikan kesempatan untuk mendiskusikan permasalahan yang berkaitan dengan Teknik berbicara menggunakan voice over. Pada akhir pelatihan, dilaksanakan praktik berupa testing suara dan perekaman suara oleh peserta dengan topik pembicaraan tertentu sebagai hasil pemahaman materi yang telah disampaikan.

\section{HASIL DAN PEMBAHASAN}

Pelatihan dilaksanakan selama satu hari pada hari Kamis, 15 Juli 2021 secara daring melalui Zoom Meeting. Pelatihan / workshop diadakan secara daring karena adanya kesenjangan waktu pelaksanaan yang bertepatan dengan penerapan Pemberlakuan Pembatasan Kegiatan Masyarakat (PPKM) yang tidak memungkinkan untuk melaksanakannya secara tatap muka / offline. Adapun tambahan ketentuan pelaksanaan pelatihan tersebut berkaitan dengan spesifikasi teknis yang harus didukung guna keberlangsungan pelaksanaan pelatihan guna menghindari kendala yang tidak diinginkan.

Tabel 1. SPESIFIKASI DUKUNGAN PERANGKAT

\begin{tabular}{ccc}
\hline \multirow{2}{*}{ Perangkat } & \multicolumn{2}{c}{ Spesifikasi } \\
\cline { 2 - 3 } & Minimum & Standar \\
\hline \multirow{2}{*}{$\begin{array}{c}\text { Core 2 Duo } \\
\text { RAngkat komputer }\end{array}$} & Core i3 \\
atau laptop & Webcam embedded & RAM 4GB \\
& Audio hardware embedded & Eebcam USB \\
\hline Perangkat & Android versi 10 & microphone kabel \\
smartphone & RAM 3GB & Android versi 12 \\
& Audio embedded & RAM 6GB \\
webcam embedded & Earphone / headset kabel \\
\hline Paket Internet & 4G kuota 2GB & 4G kuota 4GB Unlimited \\
\hline
\end{tabular}

Penyesuaian spesifikasi perangkat disesuaikan dari data yang diperoleh pada saat tahapan mapping menyesuaikan kepada kemampuan perangkat yang dimiliki oleh rata-rata peserta penelitian.
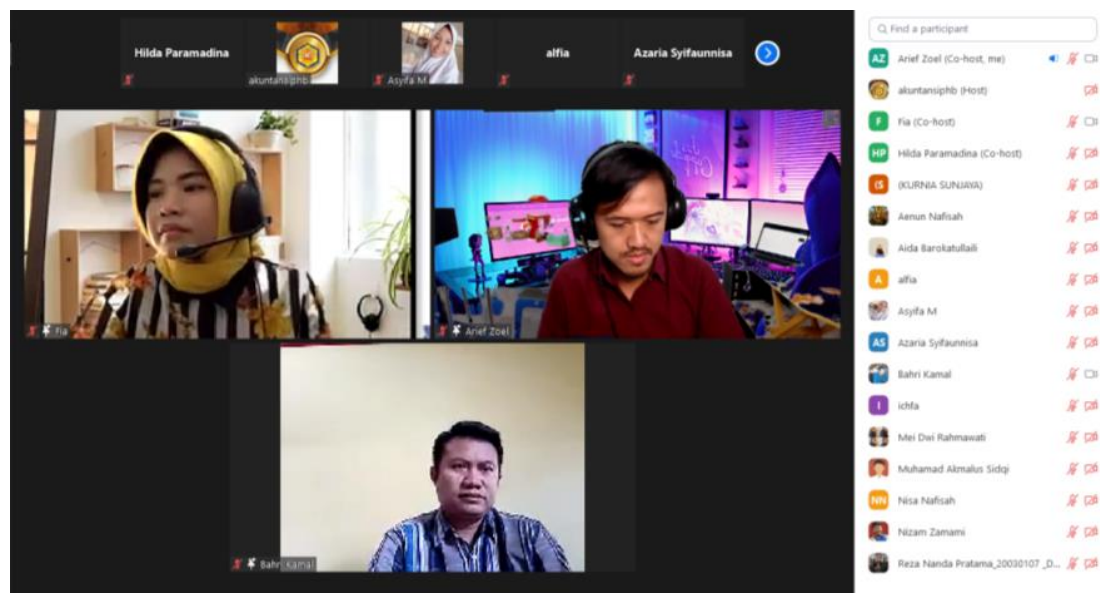

Gambar 1. PELAKSANAAN PELATIHAN MELALUI ZOOM MEETING 
Penyampaian materi disampaikan secara bergantian oleh para pengabdi sebagai pemateri dimulai dari penjelasan awal seputar serba-serbi seputar tekink berbicara, cara meningkatkan percaya diri. Materi pelatihan berkonsentrasi pada pemaparan jenis-jenis suara, pembagian klasifikasi suara, dan teknik menciptakan suara yang enak didengar oleh pendengar. Selain pembelajaran dengan metode ceramah, di setiap sesi materi, para peserta pelatihan diarahkan untuk mencoba melaksanakan praktik secara langsung sesuai dengan materi yang disampaikan.

Selain itu, pengabdi juga memberikan materi seputar peluang-peluang yang dapat dimanfaatkan oleh peserta pelatihan baik peluang secara akademik maupun peluang dalam bidang non-akademik yang dapat dimanfaatkan oleh peserta ke depan.

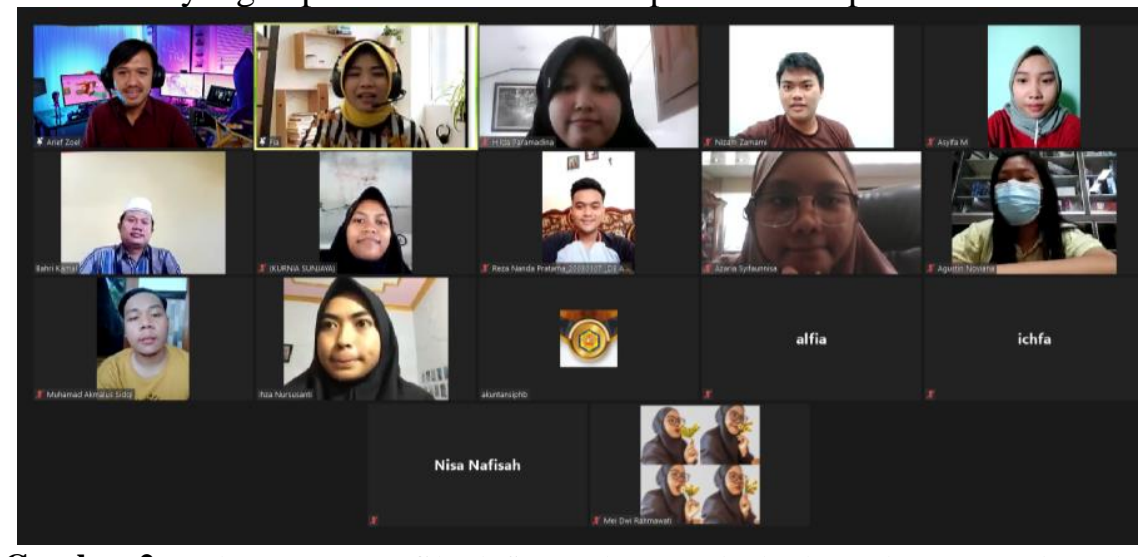

Gambar 2. PRAKTIK BERBICARA SETELAH PEMAPARAN MATERI PELATIHAN

Pada saat sebelum dan setelah pelaksanaan pengabdian, dilaksanakan pengujian singkat terhadap pengetahuan dan pemahaman seputar teknik voice over kepada mahasiswa sebagai sasaran kegiatan. Pengujian singkat ini berguna sebagai pengukuran hasil yang dicapai sebelum dan setelah pelaksanaan pengabdian.

Tabel 2. HASIL NILAI PEMAHAMAN DAN PRAKTIK VOICE OVER

\begin{tabular}{lcc}
\hline \multirow{2}{*}{ Kondisi } & \multicolumn{2}{c}{ Hasil pengujian } \\
\cline { 2 - 3 } & Pemahaman & Praktik \\
\hline $\begin{array}{l}\text { Sebelum } \\
\text { Pelatihan }\end{array}$ & 70 & 75 \\
\hline $\begin{array}{l}\text { Setelah } \\
\text { Pelatihan }\end{array}$ & 88 & 90 \\
\hline
\end{tabular}

Gambar 3. GRAFIK NILAI PENGUJIAN PELATIHAN VOICE OVER

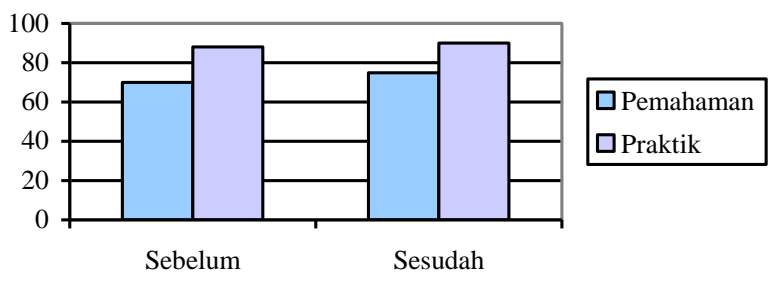

Dari hasil pengujian mendapatkan nilai keseluruhan rerata peserta adalah 70 untuk pemahaman dasar dan 75 untuk nilai praktik sebelum pelatihan diberikan. Setelah diberikan pelatihan, berupa penambahan wawasan dan pelaksanaan praktik yang mempunyai korelasi dengan materi, hasil dengan pengujian serupa mendapatkan skor 88 untuk kemampuan pemahaman dan skor 90 untuk kemampuan praktik. Perbedaan sebesar 13 poin naik untuk pemahaman / wawasan seputar teknik dan kenaikan 15 poin untuk kemampuan praktik. 
Penambahan poin dari keseluruhan pengujian dapat menunjukkan bahwa pelaksanaan kegiatan peningkatan kemampuan berbicara menggunakan teknik voice over ini memiliki dampak positif dengan bertambahnya tingkat pemahaman dan kemampuan praktik sesuai dengan materi yang disampaikan selama pendampingan pelatihan secara daring.

\section{KESIMPULAN}

Peningkatan kemampuan berbicara menggunakan teknik voice over (VO) telah terlaksana baik dan memiliki keefektivitasan yang ditunjukkan dari hasil nilai yang diambil dari pengujian singkat seputar pemahaman dan praktik. Keefektivitasan dibuktikan dengan adanya kenaikan nilai sebesar 15 poin untuk pemahaman dan kenaikan 13 poin untuk praktek. Hal ini tidak terlepas dari kesungguhan dan antusiasme para peserta dalam mengikuti pelatihan peningkatan kemampuan berbicara menggunakan teknik voice over ini.

\section{DAFTAR PUSTAKA}

Brilianti, D., \& Fithriyani, H. (2020). The Implementation of Video Blog (Vlog) as a Teaching Media in Speaking Skill. Journal of Education, Teaching and Learning, 5(2), 340-345.

Fauzi, A. Z., \& Brilianti, D. F. (2021). EKULIAH WEBSITE FOR TEACHING WRITING DESCRIPTIVE TEXT DURING THE COVID-19 PANDEMIC SITUATION. Academic Journal PERSPECTIVE: Language, Education and Literature, 9(1), 58-67. https://doi.org/10.33603/perspective.v9i1.5286.

Franco, E., Matamala, A., \& Orero, P. (2010). Voice-over translation: An overview.

Haqien, D., \& Rahman, A. A. (2020). PEMANFAATAN ZOOM MEETING UNTUK PROSES PEMBELAJARAN PADA MASA PANDEMI COVID-19. SAP (Susunan Artikel Pendidikan, 5(1).

Hsu, C.-K., Hwang, G.-J., Chang, Y.-T., \& Chang, C.-K. (2013). Effects of Video Caption Modes on English Listening Comprehension and Vocabulary Acquisition Using Handheld Devices. In Educational Technology \& Society (Vol. 16, Issue 1).

Indrianty, S. (2016). STUDENTS'ANXIETY IN SPEAKING ENGLISH (A CASE STUDY IN ONE HOTEL AND TOURISM COLLEGE IN BANDUNG). ELTIN Journal, Journal of English Language Teaching in Indonesia, 4(1).

Pawicara, R., \& Conilie, M. (2020). Analisis Pembelajaran Daring Terhadap Kejenuhan Belajar Mahasiswa Tadris Biologi Iain Jember di Tengah Pandemi Covid-19. ALVEOLI: Jurnal Pendidikan Biologi, 1(1), 29-38.

Rijanto, A., \& Rahayuningsih, S. (2021). Pelatihan dan Pendampingan Perawatan Alat Produksi Pada Usaha Mikro Kerupuk Samiler. JAMU: Jurnal Abdi Masyarakat UMUS, 1(02).

Safitri, N. ., \& Khoiriyah, I. (2017). Students' Perceptions on the Use of English Vlog (Video Blog) to Enhance Speaking Skill 1 Nailis Sa'adah Safitri, 2 Ianatul Khoiriyah. The 5th AASIC, 240-247. http://103.216.87.80/index.php/selt/article/view/7980/6083\%0Ahttp://ejournal.usd.ac.id/index.php/LLT

Thornbury, S. (2006). AZ of ELT. Macmillan Educ.

Ubaedillah, U., Pratiwi, D. I., Mukson, M., Masrikhiyah, R., \& Nurpratiwiningsih, L. . (2020). Pelatihan Wawancara Kerja Dalam Bahasa Inggris Bagi Siswa SMK Menggunakan Metode Demonstrasi. JAMU : Jurnal Abdi Masyarakat UMUS, 1(01). Dapat diunduh pada http://jurnal.umus.ac.id/index.php/jamu/article/view/317

Ur, P. (2012). A course in English language teaching. Cambridge University Press.

Vitasari, I. (2016). Kejenuhan (Burnout) Belajar ditinjau dari tingkat kesepian dan Kontrol diri pada siswa kelas XI SMA Negeri 9 Yogyakarta. Skripsi. Fakultas Ilmu Pendidikan. Universitas Yogyakarta. 